\title{
A CHROMOSOME STUDY IN SEVEN NEUROPSYCHIATRIC PATIENTS, WITH SPECIAL REGARD TO THE ABNORMALITY OF THE Y CHROMOSOME ${ }^{11}$
}

\author{
TAKASHI KATO, NOBUO TAKAGI AND SHONOSUKE MORITA \\ Department of Neuropsychiatry, School of Medicine and the Zoological Institute, \\ Faculty of Science, Hokkaido University, Sapporo
}

Received December 2, 1964

Recent rapid progress in cytogenetic techniques in mammals including man has facilitated a precise analysis of chromosomes, and a series of significant associations of chromosome abnormalities with certain congenital or hereditary disorders as well as of several pathological conditions was established in relation to their rise and cause. In most cases, the developmental abnormalities of sex have been known to occur associated with anomalies of the sex chromosomes. Recently information has been obtained that considerable variations occur in length of the $\mathrm{Y}$ chromosome in patients with various clinical conditions as well as in healthy phenotypically normal individuals, though the variability of the $\mathrm{Y}$ seems to suggest its relative inertness. It is of further importance to consider the abnormality of the $\mathrm{Y}$ in connection with the cause of certain congenital diseases, because there are reports in which such disorders are associated with the abnormal Y chromosome. While working on chromosome aberrations in male patients with neuropsychiatric diseases, the present authors encountered some patients who showed the abnormalities in length of the $\mathrm{Y}$ chromosome. In the present paper are described the results of some morphological and mensural studies of $\mathrm{Y}$ chromosomes in these patients in comparison with the normal $\mathrm{Y}$ chromosome.

\section{MATERIALS AND METHODS}

The subjects under study are as follows: two cases of an incomplete form of Laurence-Moon-Biedl's syndrome, one case of choreoathetosis and his son with similar symptoms, two cases of schizophrenia and one case of mental retardation. These patients were examined clinically and diagnosed by several neuropsychiatrists.

Chromosomes were studied in short-term cultures of leucocytes derived from peripheral blood from each individual. Chromosome preparations were made according to the modified method of Moorhead et al. (1960). For each patient under study, three

1) This paper is dedicated to Professor Sajiro Makino, Zoological Institute, Hokkaido University, Sapporo, Japan, in honor of his sixtieth birthday, June 21, 1966. 
or four karyotypes were prepared from photographs of well-defined mitotic figures, and the length of the $\mathrm{Y}$ chromosome was measured. The $\mathrm{Y}$ chromosome was identified on the basis of its fuzzy appearance and its long arm chromatids diverging less than those of other chromosomes. The ratio between the mean length of the $\mathrm{Y}$ and the mean length of chromosomes of group 13-15 which was regarded as 100 (Table 3), was then calculated. The relative length of chromosomes of groups 16-18, 19-20 and 21-22 was also calculated for comparison.

\section{RESULTS}

The results of chromosome counts are summarized in Table 2. The modal chromosome number was 46 in all the cases. It was revealed, however, that the Y chromosome was unusually long in 2 patients with an incomplete form of Laurence-Moon-Biedl's

Table 1. Clinical features of patients under study

\begin{tabular}{|c|c|c|c|c|}
\hline $\begin{array}{l}\text { Case } \\
\text { No. }\end{array}$ & Age & Sex & Diagnosis & Clinical findings \\
\hline 1 & 33 & $M$ & $\begin{array}{l}\text { Incomplete form of } \\
\text { Laurence-Moon- } \\
\text { Biedl's syndrome }\end{array}$ & $\begin{array}{l}\text { Abnormal shortness of the right big toe; extreme pro- } \\
\text { trusion of the right tibial malleolus; retinal pigmen- } \\
\text { tation; brother of a female patient with Laurence- } \\
\text { Moon-Biedl's syndrome. }\end{array}$ \\
\hline 2 & 30 & M & $\begin{array}{l}\text { Incomplete form of } \\
\text { Laurence-Moon- } \\
\text { Biedl's syndrome }\end{array}$ & $\begin{array}{l}\text { Oligodactylism of the right foot; abnormal shortness } \\
\text { of the right second toe; right cloven hand between } \\
\text { the third and fourth finger; retinal pigmentation; } \\
\text { brother of the patient no. 1. }\end{array}$ \\
\hline 3 & 42 & M & Choreoathetosis & $\begin{array}{l}\text { Loss of associated or automatic movements; muscular } \\
\text { rigidity and weakness; involuntary movements (slow, } \\
\text { sinuous, rapid and jerky). }\end{array}$ \\
\hline 4 & 14 & M & $\begin{array}{l}\text { Choreoathetosis or } \\
\text { chorea minor }\end{array}$ & $\begin{array}{l}\text { Temporary appearance of involuntary movement of the } \\
\text { neck, fingers and lower extremities; pains of the } \\
\text { right shoulder. }\end{array}$ \\
\hline 5 & 31 & $\mathrm{M}$ & Schizophrenia & $\begin{array}{l}\text { Abulia; thinking and affect disturvances; paranoid de- } \\
\text { lusions; difficulty in group relationships. }\end{array}$ \\
\hline 6 & 25 & M & Schizophrenia & $\begin{array}{l}\text { Typical paranoid type; } 3 \text { of his } 4 \text { living siblings suffer } \\
\text { from the same disease. }\end{array}$ \\
\hline 7 & 7 & M & Mental retardation & $\begin{array}{l}\text { Dysarthria (developmental dyslexia); deformity of the } \\
\text { head (skull); high palate; deformity of the bilateral } \\
\text { ring fingers. }\end{array}$ \\
\hline
\end{tabular}

syndrome (case Nos. 1 and 2) and in a patient with choreoathetosis (case No. 3) and his son (case No. 4). On the contrary, a patient with schizophrenia (case No. 5) had an unusually short Y chromosome. Another schizophrenic patient (case No. 6) had a slightly long $\mathrm{Y}$ chromosome, while that of a mentally retarded patient (case No. 7) seemed to nearly correspond to the normal $\mathrm{Y}$ in length.

In order to examine this data more critically, the length of the $\mathrm{Y}$ chromosome was 
measured in each patient and in four normal healthy males as controls. It was revealed that the unusually long $\mathrm{Y}$ chromosome ranked between chromosomes of group 16-18 and those of group 19-20 in cases 1 and 2, while in cases 3 and 4 it ranked between chromosomes of group 13-15 and those of group 16-18 (Fig. 3). In either case, the $\mathrm{Y}$ chromosome was consistently longer than that of the normal male which ranked in length between chromosomes of group 19-20 and those of group 21-22. In striking

Table 2. Chromosome conditions in 7 patients under study

\begin{tabular}{|c|c|c|c|c|c|c|c|c|}
\hline \multirow{2}{*}{$\begin{array}{l}\text { Case } \\
\text { No. }\end{array}$} & \multicolumn{6}{|c|}{ Chromosome count } & \multirow{2}{*}{$\begin{array}{c}\text { No. of cells } \\
\text { observed }\end{array}$} & \multirow{2}{*}{$\begin{array}{l}\text { Chromosome } \\
\text { constitution }\end{array}$} \\
\hline & 44 & 45 & 46 & 47 & 48 & 92 & & \\
\hline 1 & & & 20 & 1 & 1 & & 22 & $44+\mathrm{X}$, long $\mathrm{Y}$ \\
\hline 2 & & & 43 & 1 & & & 44 & $44+\mathrm{X}$, long $\mathrm{Y}$ \\
\hline 3 & 1 & & 10 & & & 1 & 12 & $44+\mathrm{X}$, long $\mathrm{Y}$ \\
\hline 4 & 4 & 6 & 61 & 1 & & & 72 & $44+\mathrm{X}$, long $\mathrm{Y}$ \\
\hline 5 & 3 & 7 & 38 & 1 & 2 & & 51 & $44+\mathrm{X}$, long $\mathrm{Y}$ \\
\hline 6 & 3 & 3 & 41 & & 1 & & 48 & $44+\mathrm{X}$, slightly long $\mathrm{Y}$ \\
\hline 7 & 1 & 9 & 23 & 1 & & & 24 & $44+\mathrm{X}, \mathrm{Y}$ \\
\hline
\end{tabular}

Table 3. Relative value in length of the $\mathrm{Y}$ and related 4 groups of autosomes in 7 patients under study and in 4 normal males as controls

\begin{tabular}{|c|c|c|c|c|c|}
\hline \multirow{2}{*}{ Case No. } & \multicolumn{5}{|c|}{ Chromosome group } \\
\hline & $13-15$ & $16-18$ & $19-20$ & $21-22$ & $\mathrm{Y}$ \\
\hline 1 & 100 & 79.4 & 64.1 & 52.8 & 72.4 \\
\hline 2 & 100 & 80.0 & 66.6 & 55.0 & 75.2 \\
\hline 3 & 100 & 84.1 & 61.1 & 42.7 & 89.2 \\
\hline 4 & 100 & 82.0 & 64.5 & 50.2 & 86.6 \\
\hline 5 & 100 & 80.3 & 63.4 & 44.2 & 37.6 \\
\hline 6 & 100 & 85.0 & 66.2 & 52.5 & 67.2 \\
\hline 7 & 100 & 78.0 & 64.1 & 49.0 & 62.2 \\
\hline Control & 100 & 82.5 & 65.4 & 50.9 & 57.9 \\
\hline " & 100 & 88.4 & 76.9 & 55.4 & 61.0 \\
\hline " & 100 & 97.9 & 70.2 & 53.6 & 59.0 \\
\hline " & 100 & 83.3 & 65.5 & 50.9 & 56.0 \\
\hline
\end{tabular}

Mean length of groups, 16-18, 19-20, 21-22 and $\mathrm{Y}$ were calculated in proportion to the mean length of chromosome group 13-15 regarded as 100 .

contrast to the above 4 cases, case No. 5 had a considerably small Y chromosome, measuring about two thirds the size of a normal $\mathrm{Y}$ and was much shorter than the chromosome 22. It must be noted that the $\mathrm{Y}$ chromosome of No. 6 patient suffering from schizophrenia was slightly longer than chromosomes of group 19-20. Relative values of the length of some related autosomes were found to be approximately the same in all the cases (Table 3). Thus it is evident that the $\mathrm{Y}$ chromosome exhibits a considerable variation in length, while there is no significant change in the size of the autosomes. 


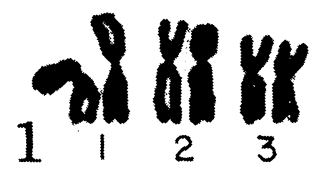

on of ha

$13 \quad 14 \quad 15$

$x_{1} x_{2} \operatorname{mat8}_{3}$

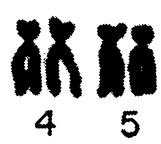

Xis no ha

$\begin{array}{lll}16 & 17 \quad 18\end{array}$

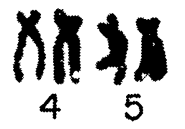

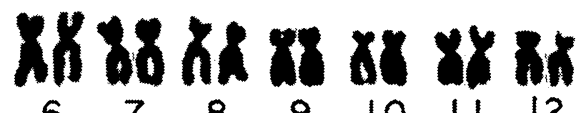

$\begin{array}{lll}6 & 7 & 8\end{array}$

$x 82 x$

$19 \quad 20$

Aa an

2122

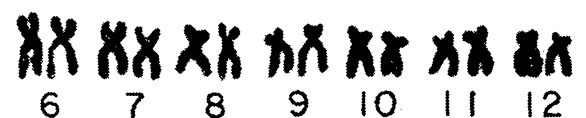

$\begin{array}{lllllll}6 & 7 & 8 & 9 & 10 & 11 & 12\end{array}$

on nn an

Ex rix an

$\begin{array}{lll}16 & i 7 \quad 18\end{array}$
คิ คิด

2) 22

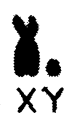

Figs. 1-2. Somatic chromosome complements based on leucocyte cultures. 1. From a patient with choreoathetosis or chorea minor (case No. 4) showing a long Y chromosome. 2. From a patient with schizophrenia (case No. 5) showing a small Y chromosome.

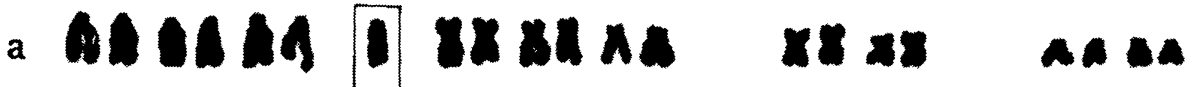

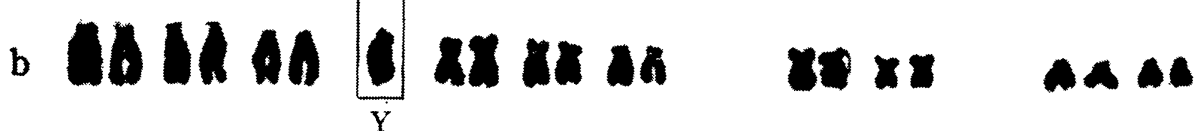

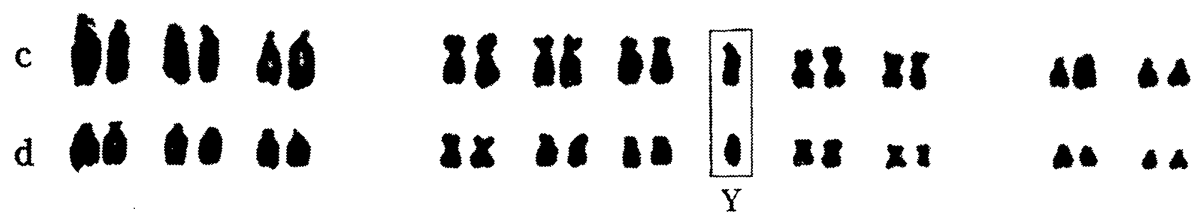

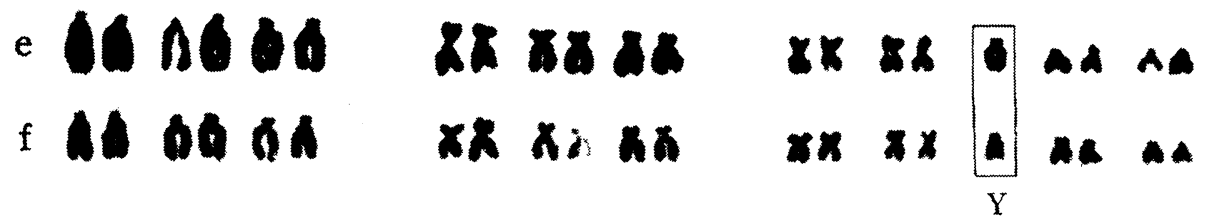

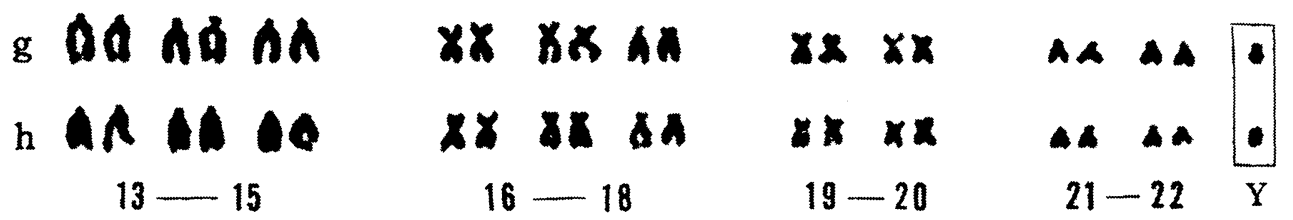

Fig. 3. Partial karyotypes of cells from 4 patients and a normal male indicating variations in length of the $\mathrm{Y}$ chromosome. a-b. From a patient with choreoathetosis or chorea minor (case No. 4) showing a long $\mathrm{Y}$ chromosome. c. From a patient with imcomplete form of L-M-B's syndrome (case No. 1) showing a long Y chromosome. d. From a patient with incomplete form of L-M-B's syndrome (case No. 2) showing a long Y chromosome. e-f. From a normal male with a normal $Y$ chromosome. $g$-h. From a patient with schizophrenia (case No. 5) showing a small Y chromosome in each. 


\section{DISCUSSION}

The human $\mathrm{Y}$ chromosome is rather easily distinguishable from autosomes, on account of its relative length and heteropycnotic nature (Chu and Giles 1959, Makino and Sasaki 1960, Patau 1960). In Denver system the Y chromosome nearly corresponds to the chromosomes of group 21-22. London Conference reports that the most common $\mathrm{Y}$ chromosome is longer than either 21 or 22 . Current literature indicates that the variability of the $\mathrm{Y}$ is observed rather frequently in man.

An unusually long $\mathrm{Y}$ chromosome corresponding in length to chromosomes of group 16-18 has been described in phenotypically normal males (Bender and Gooch 1961, Bishop et al. 1962, Makino et al. 1963 a, b, 1964 b, Makino and Muramoto 1964, Takagi et al. 1964, de la Chapelle et al. 1963), as well as in male patients suffering from various congenital disorders, such as Marfan's syndrome (Källen and Levan 1962), Down's syndrome (Bishop et al. 1962), azoospermia (van Wijck et al. 1962, Makino and Muramoto 1964), oligospermia (van Wijck et al. 1962), multiple malformations (Makino et al. 1963 a), hypogonadism (de la Chapelle et al. 1963), hypospadia penis (Makino et al. 1964 b), hyperammonemia (Makino et al. $1964 \mathrm{a}$ ) brain arterio-venous malformation (Makino et al. 1964 a), heart defect (Makino et al. $1963 \mathrm{~b}$ ), mental retardation (Makino and Muramoto 1964), and so on. On the basis of data so far obtained some authors have reported that the unusual $\mathrm{Y}$ chromosome is a heritable character, and that it is not necessarily associated with phenotypical anomalies (Bishop et al. 19j2, Makino et al. $1963 \mathrm{a}, \mathrm{b}$, de la Chapelle et al. 1963).

A short or deleted Y chromosome, on the other hand, has been reported in patients with hypospadia (Muldal and Ockey 1961). Since 3 of their 4 males showed hypospadia with mild degree of manifestation, they concluded that the deletion of the $\mathrm{Y}$ was the cause of hypospadia. Further, van Wijck et al. (1962) reported a short Y in a patient with oligospermia, and Conen et al. (1961) in an intersex patient with presumed $\mathrm{XO} / \mathrm{Xy}$ mosaicism. Vaharu et al. (1961) communicated a patient exhibiting developmental retardation and an enlarged clitoris who showed 45 chromosomes plus a fragment which seemed to be a portion of the Y. Jacobs et al. (1964) observed a metacentric Y chromosome in a normal 73-year-old man. Klevit et al. (1963) found a deleted Y and Y. isochromosome in cells from a male pseudohermaphrodite with triple mosaicism. Furthermore, Lamy et al. (1962) reported the translocation between chromosome 22 and a fragment of the $\mathrm{Y}$ resulting in the formation of a submetacentric chronosome in a regular Klinefelter patient.

The mensural examination in the present study revealed that the $\mathrm{Y}$ chromosome showed a greater variation in length than related autosomes (16-22) statistically (Table 3). At the present status of investigation, however, it remains unknown whether the abnormal length of the $\mathrm{Y}$ chromosome would reflect clinical defect or not. There were several reported cases in which phenotypically normal males possessed an unusually 
long $\mathrm{Y}$.

The Y chromosome of man is mostly heteropycnotic and carries in its longer arm a large achromatic region (Sasaki and Makino 1963). From the studies with tritiumlabeled chromosome preparations, Wennström and de la Chapelle (1963) pointed out a possibility that the large $\mathrm{Y}$ chromosome represents an elongation effect only without increase in chromatin content. Further, it has been revealed that an increase in $\mathrm{Y}$ chromatin exerts no appreciable influence on phenotype: XYY males are mostly normal fertile men, and both the XXY and the XXYY Klinefelter patients are clinically indistinguishable at present. In view of the above features, it may be reasonable to conclude that individuals with an unusually long $\mathrm{Y}$ chromosome are not necessarily associated with developmental disorders.

Muldal and Ockey (1961) have stated that various deletions of the Y chromosome give phenotypes which are intermediate between the fertile male and the Turner female. A schizophrenic male with a small $\mathrm{Y}$ (case No. 5) observed in this study, however, is otherwise normal in phenotype. Therefore, the small $\mathrm{Y}$ chromosome, in this case, must be the result of either deletion of terminal inert part of the longer arm or its overcontraction. It is of interest to note that among 17 male patients with neuropsychiatric diseases so far chromosomally examined in the Makino Laboratory, 8 patients showed an abnormality in size of the $\mathrm{Y}$ chromosome (cf. Makino et al. 1964 a, Takagi et al. 1964).

Abnormality in length of the $\mathrm{Y}$ chromosome described in the present report may be attributable to small structural rearrangements, or they may represent inherited anomalies in the structure of the heterochromatic elements.

\section{SUMMARY}

Abnormality in size of the $\mathrm{Y}$ chromosome was observed in 6 out of 7 male patients with neuropsychiatric diseases. Mensural examinations revealed that the long $\mathrm{Y}$ chromosome in cases 1 to 4 corresponded in length to chromosomes of group 16-18. Case No. 5 had a short $\mathrm{Y}$ chromosome which was much shorter than the chromosome 22 . Of special interest is that patients with neuropsychiatric defects here studied showed the anomaly in size of the $\mathrm{Y}$, although current reports indicate that the unusual length of the $\mathrm{Y}$ seems to be not necessarily associated with phenotypical anomaly in man.

The authors wish to express their sincere gratitude to Professor Sajiro Makino for his expert direction and improvement of the manuscript, and to Dr. Motomichi Sasaki for his valuable advice. Further they are obliged to Professor Nozomi Suwa, Department of Neuropsychiatry, School of Medicine, for his special interest in the subject. 


\section{LITERATURE CITED}

Bender, M. A., and P.C. Gooch, 1961 An unusually long human Y chromosome. Lancet ii : 463-464.

Bishop, A., C. E. Blank, and H. Hunter, 1962 Heritable variation in the human Y chromosome. Lancet ii : $18-20$.

Chapelle, A. de la, H. Hortling, J. Edgren, and R. Kääriäinen, 1963 Evidence for the existence of heritable large $\mathrm{Y}$ chromosomes unassociated with developmental disorder. A cytological and clinical study of 4 males with hypogonadism one with mongolism, and their relatives. Hereditas 50: 351-360.

Chu, E.H.Y., and N.H. Giles, 1959 Human chromosome complements in normal somatic cells in culture. Amer. J. Human Genet. 11: 63-79.

Conen, P.E., J. D. Bailey, W. H. Allemang, D. W. Thompson, and C. Ezrin, 1961 A probable partial deletion of the $\mathrm{Y}$ chromosome in an intersex patient. Lancet ii : 294-295.

Jacobs, P.A., M. Brunton, and W. M. Court Brown, 1964 Cytogenetic studies in leucocytes on the general population: subjects of ages 65 years and more. Ann. Human Genet. Lond. 27: 353363.

Källen, B., and A. Levan, 1962 Abnormal length of chromosomes 21 and 22 in four patients with Marfan's syndrome. Cytogenet. 1: 5-19.

Klevit, H. D., W. J. Mellman, and W. R. Eberlein, 1963 Triple mosaicism with an isochromosome derived from a partially deleted $\mathrm{y}$ in a male pseudohermaphrodite. Pediatr. 32: 56-62.

Lamy, M., J. de Grouchy, J. Frezal, N. Josso, et G. Feintich, 1962 Syndrome de Klinefelter et hypospadias. Presence de deux chromosomes X. Rupture du chromosome $\mathrm{Y}$ et translocation de ses fragments. C. R. Acad. Sci. (Paris) 255: 581-583.

Makino, S. and M. Sasaki, 1960 Chromosome constitution in normal human subjects and in one case of true hermaphroditism. Proc. Japan Acad. 36 : 156-161.

Makino, S., M. S. Sasaki, K. Yamada, and T. Kajii, 1963 a A long Y chromosome in man. Chromosoma (Berl.) 14 : 154-161.

Makino, S., K. Yamada, and G. Kohno, $1963 \mathrm{~b}$ A long Y chromosome in male twin-brothers and their father. Proc. Japan Acad. 39: 770-773.

Makino, S., N. Takagi, N. Miyamoto, S. Morita, and M. Sasaki, 1964 a Chromosomes of sixteen patients with congenital diseases. Proc. Japan Acad. 40: 134-139.

Makino, S., N. Takagi, T. Makita, and M. Hikita, $1964 \mathrm{~b}$ A chromosome study of ten sexually abnormal patients. Proc. Japan Acad. 40: 566-571.

Makino, S., and J. Muramoto, 1964 Some observations on the variability of the human Y chromosome. Proc. Japan Acad. 40 (in press).

Moorhead, P. S., P. C. Nowell, W. J. Mellman, D. M. Battips, and D. A. Hungerford, 1960 Chromosome preparations of leukocytes culturel from human peripheral blood. Exptl. Cell Res. 20: 613-616.

Muldal, S., and C. H. Ockey, 1961 Muscular dystrophy and deletion of Y chromosome. Lancet ii : 601.

Patau, K., 1960 The identification of individual chromosomes, especially in man. Amer. J. Human Genet. 12 : 250-276.

Sasaki, M.S., and S. Makino, 1963 The demonstration of secondary constrictions in human chromosomes by means of a new technique. Amer. J. Human Genet. 15: 24-33.

Takagi, N., T. Kato, and S. Morita, 1964 Chromosome studies in 10 congenital neuropsychiatric patients. Proc. Japan Acad. 40 (in press).

Vaharu, T., R. G. Patton, M. L. Voorhess, and L. I. Gardner 1961 Gonadal dysgenesis and enlarged phallus in a girl with 45 chromosomes plus "fragment". Lancet i: 1351. 
Van Wijck, J. A. M., C. A. J. Tijink, and C. A. M. Stolte, 1962 Abnormalities in the Y chromosome. Lancet i : 218 .

Wennström, J., and A. de la Chapelle, 1963 Elongation as the possible mechanism of origin of large human $\mathrm{Y}$ chromosomes. An autoradiographic study. Hereditas 50: 345-350. 